\title{
Zbigniew ŁEPKO*
}

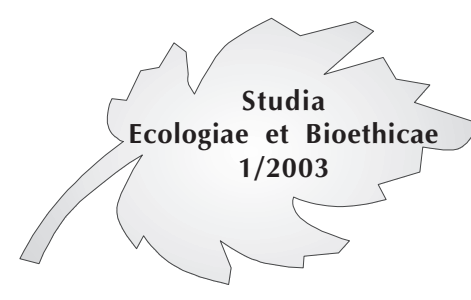

\section{Spór o socjobiologię klasyczną}

\section{Wprowadzenie}

Trwający od połowy lat siedemdziesiątych dwudziestego wieku spór o socjobiologię jest tutaj przywoływany jako współczesna odmiana prowadzonego od wielu stuleci filozoficznego sporu o naturę ludzką. Koncentrując się na uwarunkowaniach właściwych człowiekowi sposobów zachowania się, spór ten bezpośrednio nawiązywał do prowadzonego przez Williama McDougalla i Johna Watsona sporu o behawioryzm ${ }^{1}$, a także do prowadzonego przez Konrada Lorenza i Wolfganga Schmidbauera sporu o etologię ${ }^{2}$. W każdym przypadku chodziło o ustalenie czynników określających specyfikę behawioru istot żywych, w szczególności zaś człowieka. Czynnikiem tym ma być bądź wyposażenie dziedziczne, bądź też środowisko. Jednoznacznie wspierając ideę genetycznego determinizmu ludzkiego bahawioru, socjobiolodzy sprowokowali dramatyczny spór, którego próby rozwiązania doprowadziły jedynie do zawieszenia broni, gotowej do użycia przy najbliższej nadarzającej się ku temu okazji ${ }^{3}$.

\section{Geneza sporu}

Geneza sporu o socjobiologię sięga genezy samej socjobiologii. Jej powstanie było odpowiedzią na narastające wśród biologów ewolucyjnych oczekiwanie wyjaśnienia zagadkowych dla etologii społecznych zachowań zwierząt, takich jak altruizm i kooperacja. Zachowania te były zresztą zagadką dla samego Darwina, który łamał sobie głowę nad możliwością uzgodnienia faktu bezpłodności pewnych kast owadów społecznych

\footnotetext{
Instytut Ekologii i Bioetyki Uniwersytetu Kardynała Stefana Wyszyńskiego w Warszawie.

1 Por. J. Pieter, Historia psychologii w zarysie, Katowice 1959, 144.

2 Por. W. Schmidbauer, Methodenprobleme der Human-Ethologie, „Studium Generale” 24(1971)462-494; Por. K. Lorenz, Der Mensch, biologisch gesehen. Eine Antwort an Wolfgang Schmidbauer, „Studium Generale” 24(1971)495-515.

3 Por. Z. ŁEPKo, Nowa antropologia Edwarda Wilsona, „Seminare” (1994) 10, 245-257.
} 
z przejawami ich altruizmu wobec młodszego rodzeństwa. Zagadka tych zachowań stanowiła pierwszorzędne wyzwanie badawcze i stwarzała niejako presję na biologów w dążeniu do jej szybkiego wyjaśnienia. Wyrazem tego dążenia była zorganizowana w 1948 r. nowojorska sesja naukowa, na której podjęto próbę porozumienia ekologów, fizjologów i socjologów na rzecz porównawczego badania sposobów społecznego zachowania się istot żywych. Wtedy też ten interdyscyplinarny kierunek nazwano socjobiologią .

Niestety ta inicjatywa utknęła na deklaracjach programowych. Historycy nauki podkreślają, że główną przyczyną nieudanej próby wykorzystania pierwszego pomysłu na socjobiologię był brak związania go z jakąś "teorią nośną", rozszerzającą dotychczasowe możliwości badań nad sposobami społecznego zachowania się istot żywych. Dążenie do wypracowania takiej teorii stało się więc głównym wyzwaniem dla wielu badaczy. Na szczególną uwagę w tym względzie zasługują prace V. C. Wynne-Edwardsa ${ }^{5}$ i W. D. Hamiltona ${ }^{6}$.

V. C. Wynne-Edwards szansę uzgodnienia występującego w świecie zwierząt zjawiska rezygnacji z własnego potomstwa z faktem selekcji nastawionej na przetrwanie osobnika dostrzegł w koncepcji doboru grupowego. Zgodnie $\mathrm{z}$ tym ujęciem rezygnacja $\mathrm{z}$ własnego potomstwa wymuszana jest czynnikami ekologicznymi. Ewentualny wzrost liczebny danej populacji ograniczałby bowiem swobodny dostęp do zasobów pożywienia na danym terenie i tym samym zmniejszałby szansę przetrwania danej populacji w stosunku do populacji konkurencyjnych. Oznacza to, że rezygnacja z własnego potomstwa zwiększałaby sprawność konkurencyjną tej populacji. Tak rozumiany dobór grupowy, zdaniem WynneEdwardsa, stwarzał możliwość tłumaczenia nie tylko zdolności populacji do kontroli swej liczebności, ale także istnienia międzyosobniczych zachowań altruistycznych. Koncepcja doboru grupowego nie sprzyjała jednak wyjaśnieniu, w jaki sposób takie korzystne dla populacji skłonności do rezygnacji z własnego potomstwa utrwalają się z pokolenia na pokolenie w sytuacji, gdy w grę nie wchodzi rozmnażanie się. Ta słabość koncepcji doboru grupowego rozstrzygała o jej niedarwinowskim charakterze. Nie kończyła więc poszukiwań rozwiązania Darwinowskiego dylematu w sprawie altruistycznych sposobów zachowania się zwierząt.

4 W. Wickler, U. Seibt, Das Prinzip Eigennutz. Ursachen und Konsequenzen sozialen Verhaltens, München 1981, 79.

5 V. C. Wynne-Edwards, Animal dispersion in relation to social behaviour, Edinburgh-London 1962.

6 W. D. Hamilton, The Gentical Theory of Social Behaviour, „Journal of Theoretical Biology” (1964) 7, 1-32. 
Historycy nauki przyjmują, że próby rozwiązania tego dylematu zakończyły się powodzeniem $\mathrm{w}$ połowie lat sześćdziesiątych ubiegłego stulecia7. W 1964 r. W. D. Hamilton zauważył bowiem, że możliwość wyjaśnienia sposobów społecznego zachowania się istot żywych stwarza założenie, iż jednostką doboru naturalnego nie jest populacja czy osobnik, lecz jednostkowy gen. To doprowadziło do koncepcji doboru krewniaczego, czyli działającego na korzyść grupy krewnych o takich samych genach, sprzyjających sukcesowi reprodukcyjnemu. W świetle tej koncepcji okazało się, że zachowania altruistyczne u zwierząt są zawsze interesowne. Ich celem jest bowiem sukces reprodukcyjny genów altruisty bez względu na to, gdzie są one ulokowane ${ }^{8}$. Ważną rolę w tym sukcesie odgrywa zatem skuteczna, czyli adekwatna do zaistniałych warunków środowiskowych strategia behawioralna, przebiegająca zgodnie z regułami teorii gier $^{9}$. Koncepcja doboru krewniaczego została tym samym uzupełniona przez koncepcję strategii ewolucyjnie stabilnej, czyli bardziej od innych sprzyjającej przetrwaniu ${ }^{10}$.

Stworzona przez Hamiltona populacyjno-genetyczna teoria doboru krewniaczego stanowiła ową "teorię nośną", umożliwiającą spożytkowanie zrodzonego w 1948 r. pomysłu na socjobiologię. Do tego pomysłu z powodzeniem nawiązał E. O. Wilson, publikując w 1975 r. książkę "Socjobiologia - nowa synteza"11. To właśnie jej przesłanie stało się przedmiotem gwałtownego sporu ${ }^{12}$.

\section{Przedmiot sporu}

E. O. Wilson zdefiniował socjobiologię jako „systematyczne badanie biologicznych podstaw wszelkich form społecznego zachowania się (włącznie z seksualnym zachowaniem się i zachowaniem się rodziców względem swoich dzieci) organizmów żywych, włącznie z człowiekiem"13. Podkreślał przy tym, że traktuje ona społeczności jako popula-

W. Wicker, Von der Ethologie zur Soziobiologie, w: J. Herbig, R. Hohlfeld (red.), Die zweite Schöpfung. Geist und Ungeist in der Biologie des 20. Jahrhunderts, München-Wien 1990, 178.

8 T. BIELICKI, O pewnej osobliwości cztowieka jako gatunku, „Znak” XLV (1993) 1, 22-40.

9 J. Meynard Smith, Evolution and the theory of game, Cambridge 1982.

10 A. Łomnicki, Strategia ewolucyjnie stabilna, „Kosmos” 36(1987) 3, 357-374.

11 E. O. Wilson, Sociobiology: The New Synthesis, Cambridge Mass. 1975.

12 Por. A. Unbanek, Między egoizmem, altruizmem i agresją: spór o socjobiologię, w: St. Nowak (red.), Wizje człowieka i społeczeństwa w teoriach i badaniach naukowych, Warszawa 1984, 155-187. Por. B. Szacka, Stowo wstępne, w: E. O. WiLson, O naturze ludzkiej, przekł. B. Szacka, Warszawa 1978, 5-19.

13 Ch. J. Lumsden, E. O. Wolson, Das Feuer des Prometheus. Wie das menschliche Denken entstand. Vorwort von Wolfgang Wickler, München-Zürich 1983, 45. 
cje, funkcjonujące według praw zorganizowanych systemów, nadrzędnych w stosunku do płaszczyzny izolowanych osobników. Każda taka populacja ma określoną wielkość, wspólną strukturę genetyczną, określony stosunek liczbowy między osobnikami żeńskimi i męskimi, system komunikacji itd. Wilson utrzymywał, że czasowe zmiany tych cech można badać tak samo, jak dane chemiczne i anatomiczne ${ }^{14}$. To sprawia, że socjobiologia jest całkowicie wierna przyrodoznawstwu, a jej program badawczy, identyfikowany jako materializm naukowy, powinien opierać się na „bezkompromisowym zastosowaniu teorii ewolucji do wszystkich aspektów ludzkiej egzystencji"15. Celem jej badań jest zaś dążenie do stworzenia syntezy nauk społecznych i przyrodniczych. Wilson uznawał bowiem, że "socjologia, jak również inne nauki społeczne i humanistyczne są ostatnimi gałęziami biologii, które czekają na włączenie do nowoczesnej syntezy"16.

Przez tę syntezę Wilson rozumiał neodarwinowską teorię ewolucji, w ramach której każde zjawisko biologiczne podlega ocenie według swojej wartości przystosowawczej i jest wiązane z zasadami genetyki populacyjnej. Dlatego też jedno z głównych zadań socjobiologii upatrywał Wilson $\mathrm{w}$ takim przeformułowaniu podstaw nauk społecznych, aby mogły one zostać włączone do tej nowoczesnej syntezy. Oznacza to, że celem socjobiologii jest ostatecznie przyrodoznawcza teoria społeczeństwa ludzkiego. Zdaniem Wilsona takie podejście jest konieczne ze względu na nieuniknione $\mathrm{w}$ przyszłości genetyczne planowanie ludzkich społeczeństw. W ten sposób Wilson przedstawił socjobiologiczną wersję redukcjonistycznej tezy E. W. Counta, że „kultura jest właściwym człowiekowi wyrazem biogramu kręgowców"17.

\section{Przebieg sporu}

Wysunięta przez Wilsona ogólna teza, że prawidłowości, które dobrze stosują się do zwierząt mogą być z powodzeniem spożytkowane przez nauki społeczne, tuż po jej opublikowaniu zrodziła kontrowersje początkujące gwałtowny spór o socjobiologię. Wilson twierdzi, że stanowił on nową wersję starego sporu o ustalenie czynnika determinującego zachowanie się istot żywych ${ }^{18}$. Czynnikiem tym ma być bądź wyposaże-

\footnotetext{
Tamże, 65-66.

E. O. WILson, O natorze ludzkiej, 24.

E. O. WILson, Sociobiology: New Synthesis, 4.

17 E. W. Count, The Biological Basis of Human Sociality, „American Anthropologist” (1958)60, 1049.

18 Ch. J. Lumsden, E. O. Wilson, Das Feuer des Prometheus, 63-76.
} 
nie dziedziczne, bądź środowisko. Socjobiolodzy od początku zajęli w tym względzie jednoznaczne stanowisko. Uznali mianowicie, że tym czynnikiem jest wyposażenie dziedziczne.

Spór o socjobiologię w pierwszym rzędzie dotyczył więc idei genetycznego determinizmu sposobów społecznego zachowania się istot żywych, w szczególności zaś człowieka. W sporze tym brali udział z jednej strony socjobiolodzy, z drugiej zaś lewicujący naukowcy i studenci skupieni w założonej latem 1975 r. w Bostonie organizacji, noszącej nazwę "The Sociobiology Study Group of Science for the People". W jej ramach powstała z czasem specjalna grupa studyjna w celu analizowania społecznych reperkusji teorii socjobiologicznych ${ }^{19}$. Wilson mówi o gwałtownym charakterze tego sporu i wskazuje na dwa jego etapy: etap sporu politycznego i etap sporu merytorycznego ${ }^{20}$.

Na pierwszym etapie sporu przeciwnicy Wilsona podkreślali polityczne niebezpieczeństwo, jakie niesie ze sobą zastosowanie tez socjobiologii ogólnej do opisów i analiz funkcjonowania społeczeństw ludzkich. Taki zabieg stanowiłby bowiem powrót do idei darwinizmu społecznego (socjaldarwinizmu) i niejako z założenia usprawiedliwiałby status quo społeczeństw kapitalistycznych, utrzymujących przywileje stosownie do klasy, rasy i płci. Postulowali więc zarzucenie socjobiologicznych spekulacji na rzecz prawdziwej nauki dla ludu, czyli nauki służącej biednym i uciskanym.

Wilson zaś odpowiadał, że najsłabszym punktem argumentacji jego przeciwników jest właśnie narzucanie odkryciom naukowym kryteriów politycznych. Zgoda na te kryteria nieuchronnie musi sprowadzić te badania na manowce. Zdaniem Wilsona najlepszą tego ilustracją jest zaczerpnięta $\mathrm{z}$ niedawnej przeszłości pseudogenetyka, praktykowana $\mathrm{w}$ hitlerowskich Niemczech, i łysenkoizm, znajdujący podatny grunt $\mathrm{w}$ Związku Radzieckim. W tej sytuacji Wilson uznał, że z przyczyn pozanaukowych merytoryczna dyskusja z przedstawicielami "Science for the People” jest niemożliwa. Dążą oni bowiem do „spalenia na stosie Darwina, aby uratować Marksa"21.

Drugi etap sporu mial, zdaniem Wilsona, charakter merytoryczny ${ }^{22}$. Na tym etapie krytycy przyznawali, że socjobiologia trafnie orzekając o społecznym behawiorze zwierząt, jedynie w ograniczonym zakresie adekwatnie odnosi się do społecznego behawioru człowieka. O ile więc można wskazać na zgodność tez socjobiologii zwierząt z pewnymi szczegółowymi zjawiskami występującymi w społecznym behawiorze człowieka, jak choćby nepotyzm, terytorializm czy zakaz incestu, o tyle nie do zaak-

19 Por. Sociobiology Study Group of Science for the People, Sociobiology-Another Biological Determinism, „Bioscience” 26(1976)3.

20 Ch. J. Lumsden, E. O. Wilson, Das Feuer des Prometheus, 63-76.

21 Tamże, 73. 
ceptowania są próby odnoszenia tez socjobiologii do całości zjawisk występujących w sferze obyczajowości człowieka. Człowiek nie jest bowiem automatem, funkcjonującym zgodnie z rozkazami genów, gdyż ma wolną wolę i umysł stanowiący zasadę autonomicznego życia kultury. Stąd też cała sfera umysłowego życia człowieka w sposób oczywisty wymyka się opisom i analizom darwinowskim i socjobiologicznym.

\section{Próba rozwiązania sporu}

Krytykę akcentującą niepełną adekwatność socjobiologii do społecznego behawioru człowieka Wilson uznał za zasadną. W tym sensie gwałtowny spór o socjobiologię wyłożoną w 1975 r. został, przynajmniej w środowisku uniwersyteckim Harvardu, formalnie zamknięty. Podsumowaniem tego sporu był precyzyjny wykład socjobiologii klasycznej zawarty przez Wilsona w książce z 1978 r. pt. „O naturze ludzkiej”23. Tym samym nie została jednak zamknięta kwestia socjobiologii człowieka. Możliwość jej rozwiązania Wilson dostrzegł w analizach problemu ludzkiego umysłu, świadomości, wolnej woli i wielości kultur, a więc osobliwości antropologicznych, które wymykają się bezpośrednim analizom darwinowskim i socjobiologicznym. Problemy te podjął we współpracy z Ch. J. Lumsdenem, a wyniki prób ich rozwiązania przedstawił w dwóch kolejnych książkach: „Geny, umysł, kultura”24 i „Ogień Prometeusza”25.

W obu tych pracach Wilson uznał, że adekwatne do faktycznego stanu rzeczy ujęcie umysłu i kultury musi uwzględnić zjawisko koewolucji genetyczno-kulturowej, rozumianej jako model rekonstruujący drogę do tajemnicy ludzkiej natury, czyli do źródeł ludzkich uzdolnień moralnych i poznawczych. Zgodnie z tym ujęciem koewolucja genetyczno-kulturowa stanowi model-postulat, który „na sposób nowoczesnej nauki ujmie wielki proces przyczyn i skutków, prowadzący od genów do architektury mózgu i dalej od sterujących rozwojem umysłowym reguł epigenetycznych poprzez powstawanie kultury, wreszcie poprzez dobór naturalny i inne czynniki ewolucji z powrotem do ewolucji genów"26. Te źródła Wilson utożsamił z fizyczną bazą myślenia moralnego, a ich odkrycie uznał za podstawę możliwości intelektualnego porozumienia przedstawicieli różnych typów poznania w sprawie funkcjonowania natury ludzkiej. Chodzi mianowicie o

\footnotetext{
Tamże, 74-76.

E. O. Wilson, On Human Nature, Cambridge 1978.

Ch. J. Lumsden, E. O. Wilson, Genes, Mind and Culture, Cambridge 1981.

25 Ch. J. Lumsden, E. O. Wilson, Promethean Fire. Reflections on the Origin of Mind, Cambridge-London 1983.

26 Ch. J. Lumsden, E. O. Wilson, Das Feuer de Prometheus, 237.
} 
przedstawicieli takich dziedzin ludzkiej wiedzy, jak fizjologia mózgu, informatyka, psychologia, językoznawstwo, antropologia, etologia, genetyka, neurofizjologia, socjobiologia i filozofia. Wilson twierdzi, że wszystkie te dziedziny ludzkiego poznania koncentrują się na badaniu ludzkiego umysłu, dzięki czemu tworzą faktycznie jedną dyscyplinę poznawczą, powstałą w wyniku ich implosywnej konwergencji. Zdaniem Wilsona $\mathrm{w}$ ten sposób powstaje nowa antropologia, albo nowa humanistyka ${ }^{27}$.

Intelektualnemu porozumieniu uczonych $\mathrm{w}$ ramach postulowanej przez Wilsona nowej antropologii powinien towarzyszyć właściwy dla socjobiologii klasycznej duch materializmu naukowego, aktualizujący się w "bezkompromisowym zastosowaniu teorii ewolucji do wszystkich aspektów ludzkiej egzystencji" ${ }^{\prime 28}$. Temu porozumieniu powinno też przyświecać dążenie do obiektywnego prześwietlenia natury ludzkiej, umożliwiającego porozumienie w sprawie zasięgu funkcjonowania tej natury. Zgoda co do natury ludzkiej konsekwentnie musi prowadzić do zjednoczenia działań na rzecz najlepszego wykorzystania ustaleń naukowych w celu planowania społeczeństw ludzkich. Celem nowej antropologii jest więc ostatecznie doskonalenie form inżynierii społecznej, dotykającej najgłębszych pokładów ludzkich motywacji i sądów moralnych ${ }^{29}$. W ten sposób Wilson powrócił do przewodniej myśli socjobiologii klasycznej, dążącej do przyrodoznawczej teorii społeczeństwa, na podstawie której możliwe stanie się faktyczne konstruowanie ludzkich społeczeństw w przyszłości.

\section{Wnioski}

Podjęte przez Wilsona próby rozwiązania spornych kwestii socjobiologii człowieka okazały się nieskuteczne. $\mathrm{W}$ istotnych kwestiach Wilson pozostał wierny programowi badawczemu socjobiologii klasycznej, adekwatnej jedynie do homogenicznych sposobów zachowania się istot żywych. Tymczasem wiadomo, że w wielu zjawiskach behawioralnych ujawniają się także programy heterogeniczne. W. Wickler ${ }^{30}$ przypomina $\mathrm{W}$ związku z tym, że np. wiele pasożytów wpływa w określony sposób na zachowanie się swoich gospodarzy, raz przynosząc im straty, innym razem zyski. Wiadomo ponadto, że znaczna część behawioralnego programu zwierząt wyższych nie jest uwarunkowana genetycznie; wymaga więc uczenia się i odniesień do "tradycji". Śpiew wielu gatunków ptaków składa się np. z wyuczonych "dialektów”. Tego rodzaju śpiewy stanowią sposoby zachowania się oparte na przekazach z pokolenia na pokolenie. Przy

\footnotetext{
Tamże, 236

28 E. O. Wilson, O naturze ludzkiej, 24.

29 Ch. J. Lumsden, E. O. Wilson, Das Feuer des Prometheus, 255-257.

30 Por. W. Wickler, Dialekte im Tierreich, Münster 1986.
} 
czym nie dysponujemy metodami badawczymi, przy pomocy których można by stwierdzić, czy śpiewy te mają charakter przystosowawczy. Z pewnością wiadomo jednak, że śpiewy ptaków, jako przekazywany z pokolenia na pokolenie środek komunikowania się, wpływają na wybór partnera seksualnego, a więc rozstrzygają o możliwości rozmnażania się. Oznacza to, że śpiewy te mają wpływ na ewolucję genetyczną. Na tej podstawie można przypuszczać, że wraz ze wzrastającym znaczeniem warunkowanego tradycją zachowania się, geny mogą zostać zdominowane przez tę tradycję. Na tej podstawie W. Wickler ${ }^{31}$ odrzuca przeświadczenie E. Wilsona, że programy genetyczne zawsze zdominują tradycję.

Choć socjobiologia klasyczna rzuciła nowe światło na zjawiska behawioralne i tym samym rozszerzyła możliwości poznawania i rozumienia sposobów zachowania się istot żywych, to jednak $\mathrm{w}$ konfrontacji $\mathrm{z}$ przedmiotowym bogactwem przyrody ujawniła równocześnie swoje poznawcze ograniczenia. Efektywna w opisywaniu i analizowaniu homogenicznych programów behawioralnych, socjobiologia pozostała bezradna wobec programów heterogenicznych. Próby objęcia badaniem socjobiologicznym heteronomicznych sposobów zachowania się muszą więc w dalszym ciągu budzić wątpliwości, a w konkretnych przypadkach powinny być uznane za metodologiczną uzurpację. Oznacza to, że socjobiologiczne orzekanie o człowieku, dysponującym najszerszym spośród istot żywych zakresem heteronomicznych sposobów zachowania się nadal będzie rodziło nowe odmiany starego sporu o socjobiologię. Dzisiaj mógłby on na przykład przybrać postać sporu o psychologię ewolucyjną

\section{The dispute about classical sociobiology}

\section{SUMMARY}

"Sociobiology: New Synthesis" is a book written by W. O. Wilson, which in 1975 started the famous dispute about sociobiology. The dispute is the contemporary version of the old one about the nature of man. The issue concerns the factor, which determines behaviors of living organisms, especially human beings. There were two groups who took part in that dispute. On one side, there were sociobiologists under the leadership of Wilson. On other, there were left-wing scientists and students connected with Sociobiology Study Group of Science for the People. In the first stage, the dispute was very intense and political, however it soon became more content-related. The dispute is not over yet. Both sides agreed for a ceacefire, but they are ready to open it at any time.

31 W. WICKLER, Von der Ethologie zur Soziobiologie, 184.

32 Por. D. M. Buss, Psychologia ewolucyjna, Gdańsk 2001. 